\title{
Protective effect of Arque-Ajeeb on acute experimental diarrhoea in
}

\section{rats}

\author{
Mohd Aleem Khan*1, Naeem Ahmad Khan1, Iqbal Ahmad Qasmi ${ }^{1}$, \\ Ghufran Ahmad ${ }^{1}$ and Shadab Zafar ${ }^{2}$
}

Address: ${ }^{1}$ Department of Ilmul Advia (Pharmacology), Faculty of Unani Medicine, Aligarh Muslim University, Aligarh-202002, Uttar Pradesh, India and ${ }^{2}$ Medical Officer, Unani Dispensary, Municipal Corporation of Delhi, Jhatikra, New Delhi-110043, India

Email: Mohd Aleem Khan* - mohdaleemkhan_amu@rediffmail.com; Naeem Ahmad Khan - naeemahmadkhan@rediffmail.com; Iqbal Ahmad Qasmi - iqbalahmadqasmi@rediffmail.com; Ghufran Ahmad - ghufranahmad_amu@rediffmail.com; Shadab Zafar - shadab_zafar@rediffmail.com

* Corresponding author

Published: 06 July 2004

BMC Complementary and Alternative Medicine 2004, 4:8 doi:10.1 186/1472-6882-4-8
Received: II April 2004

Accepted: 06 July 2004

This article is available from: http://www.biomedcentral.com/l472-6882/4/8

(C) 2004 Khan et al; licensee BioMed Central Ltd. This is an Open Access article: verbatim copying and redistribution of this article are permitted in all media for any purpose, provided this notice is preserved along with the article's original URL.

\begin{abstract}
Background: Diarrhoea is a major health problem for children worldwide, accounting for 5-8 million deaths each year. Arque-Ajeeb $(A A)$ is a compound formulation of Unani medicine. It is reputed for its beneficial effects in the treatment of diarrhoea and cholera, but the claim of its efficacy is yet to be tested. Therefore the present study has been planned to investigate the real efficacy of this drug in rats.

Methods: The effect of Arque-Ajeeb was investigated for antidiarrhoeal activity against charcoalinduced gut transit, serotonin-induced diarrhoea and $\mathrm{PGE}_{2}$-induced small intestine enteropooling in rats. The control, standard and test groups of experimental animals were administered with normal saline (p.o.), diphenoxylate hydrochloride $(5 \mathrm{mg} / \mathrm{kg}$, p.o.) and Arque-Ajeeb $(0.07 \mathrm{ml}$ and 0.14 $\mathrm{ml} / \mathrm{kg}$, p.o.) respectively except the control group of $\mathrm{PGE}_{2}$-induced small intestine enteropooling which received only $5 \%$ ethanol in normal saline (i.p.). Charcoal ( $10 \mathrm{ml} / \mathrm{kg}$, p.o.) and serotonin $(600$ $\mu g / \mathrm{kg}$, i.p.) were administered after $30 \mathrm{~min}$, while $\mathrm{PGE}_{2}(100 \mu \mathrm{g} / \mathrm{kg}$, p.o.) was administered immediately afterwards. The distance traveled by charcoal in small intestine was measured after 15 and $30 \mathrm{~min}$ of charcoal administration, diarrhoea was observed every 30 -min for six hour after serotonin administration and the volume of intestinal fluid was measured after 30 min of PGE $_{2}$ administration.

Results: Arque-Ajeeb $(0.07 \mathrm{ml}$ and $0.14 \mathrm{ml} / \mathrm{kg})$ significantly inhibited the frequency of defaecation and decreased the propulsion of charcoal meal through the gastrointestinal tract, reduced the wetness of faecal droppings in serotonin-induced diarrhoea and also reduced the $\mathrm{PGE}_{2}$-induced small intestine enteropooling.
\end{abstract}

Conclusion: Arque-Ajeeb may have potential to reduce the diarrhoea in rats. Thus the drug may prove to be an alternate remedy in diarrhoea.

\section{Background}

Diarrhoea is a major health problem especially for chil- dren under the age of 5 years and up to $17 \%$ of all death in the indoor pediatrics patients is related to diarrhoea. 
Worldwide distribution of diarrhoea accounts for more than 5-8 million deaths each year in infants and small children less than 5 year especially in developing countries [1]. According to WHO estimation for the year 1998, there were about 7.1 million deaths due to diarrhoea [2].

Arque-Ajeeb (Arque-e-Hayat, Zam Zam, Qulzum, Akseer-eAzam) is a compound formulation of Unani medicine containing Satt-e-Podina (plant extract of Mentha arvensis Linn), Satt-e-Ajwain (seeds extract of Trachyspermum ammi Linn) and Kaphoor (Camphor). It is reputed for its beneficial effects in treatment of diarrhoea [3] and cholera [4], but the claim of the efficacy is yet to be tested. The drug is said to possess antispasmodic, digestive [5] and antifltulant [6] properties. Therefore the present study has been planned to investigate the real efficacy of $A A$ in rats. The goal of this study is to find out the effective dose of $A A$ and its ameliorating potential in diarrhoea as a supporting evidence of its antidiarrhoeal property.

\section{Methods \\ Drugs}

Satt-e-Podina, Satt-e-Ajwain and Kaphoor were procured from Dawakhana Tibbia College, Aligarh Muslim University, Aligarh, India. Activated charcoal (Sarabhi M. Chemical Ltd. India), serotonin creatinine sulphate (ICN Biomedical, Ohio), $\mathrm{PGE}_{2}$ (Astra-IDL, India) and Diphenoxylate hydrochloride (lomotil) (Searle India Ltd.) were procured from their respective sources. Fresh solution of activated charcoal $(10 \%)$ and diphenoxylate were prepared in distilled water and $\mathrm{PGE}_{2}$ was prepared in $5 \%(\mathrm{v} /$ v) ethanol in normal saline before administration.

\section{Preparation of Arque-Ajeeb (AA)}

All the three constituents viz: Satt-e-Podina, Satt-e-Ajwain and Kaphoor were mixed in equal (1:1:1 gm) ratio. After mixing, it turns into liquid form and known as ArqueAjeeb [7]. It was diluted with distilled water before administration.

\section{Animals}

Wistar albino rats (150-200 gm) of either sex were procured from Laboaid animal house, Meerut, India and provided food and water ad libitum. All the animals were maintained under laboratory conditions for an acclimatization period of seven days before performing the experiments. All studies were carried out using six rats in each group. The experiments were performed between 09:00 and 17:00 hrs. The animal ethics committee of Aligarh Muslim University approved the study protocol.

\section{Experimental design}

\section{Charcoal-induced gut transit}

The method of Jabbar et al [8] was followed. Non-fasted animals were divided in to four groups of six each. Group
I and II were treated with normal saline $(2 \mathrm{ml} / \mathrm{rats})$ and standard (diphenoxylate hydrochloride, $5 \mathrm{mg} / \mathrm{kg}$ ), while group III and IV were treated with $A A(0.07$ and $0.14 \mathrm{ml} /$ $\mathrm{kg}$ ) respectively. All the doses of control, standard and $A A$ were administered orally and after 30 min activated charcoal solution $(10 \mathrm{ml} / \mathrm{kg})$ was administered orally in each group.

All the animals of each group were divided into two subgroups. Under deep ether anaesthesia half animals of each group were sacrificed after $15 \mathrm{~min}$ and another half animals were sacrificed after 30 min of charcoal administration. Small intestines of each animal were removed surgically and the distance traveled by charcoal was measured and expressed as a percentage of the total length of small intestine (from pylorus to the ileocoecal junction).

\section{Serotonin-induced diarrhoea}

The method of Jabbar et al [8] was followed. Non-fasted animals were divided in to four groups of six each. Group I and II were treated with normal saline $(2 \mathrm{ml} / \mathrm{rats})$ and standard (diphenoxylate hydrochloride, $5 \mathrm{mg} / \mathrm{kg}$ ), while group III and IV were treated with $A A(0.07$ and $0.14 \mathrm{ml} /$ $\mathrm{kg})$. All the doses of control, standard and $A A$ were administered orally and after $30 \mathrm{~min}$ serotonin $(600 \mu \mathrm{g} / \mathrm{kg})$ was administered intraperitoneally in each group. After the administration of serotonin suspension each animal were kept in a separate cage and examined every $30 \mathrm{~min}$ for the presence of diarrhoea up to $6 \mathrm{hr}$.

Diarrhoea was defined as the presence of fluid in the stool, which stained the absorbent paper placed beneath the cage. The total number of respondents and the number of stools passed during the $6 \mathrm{hrs}$ period were recorded for each rat. The purging index (PI) was calculated by the following formula:

$$
\mathrm{PI}=\frac{\% \text { respondents } \mathrm{X} \text { average number of stool }}{\text { Average latent period }}
$$

PGE2-induced small intestine enteropooling

The method of Biswas et al [9] was followed. Non-fasted animals were divided in to four groups of six each. Groups I and II were treated with $1 \mathrm{ml}$ of $5 \%(\mathrm{v} / \mathrm{v})$ ethanol in saline intraperitoneally, while the groups III and IV were treated with $A A(0.07 \mathrm{ml}$ and $0.14 \mathrm{ml} / \mathrm{kg})$ orally. Group I was then administered with normal saline $(1 \mathrm{ml} / \mathrm{rat})$ orally and utilized as control. Immediately afterwards, $\mathrm{PGE}_{2}(100 \mu \mathrm{g} / \mathrm{kg}$ in $5 \% \mathrm{v} / \mathrm{v}$ ethanol in normal saline) was administered orally to each rat except the group I which received only $5 \%$ ethanol in normal saline and control vehicle. After 30 min under deep ether anaesthesia all the animals were sacrificed. Small intestines (from pylorus to the ileocoecal junction) of each animal were removed surgically and its contents was measured. 
Table I: Effect of $A A$ on charcoal-induced gut transit changes

\begin{tabular}{llll}
\hline Groups & Doses & Distance traveled by charcoal in cm (Mean \pm S.E.M.) \\
\hline & & After I5 min & After 30 min \\
\hline Control (saline) & $2 \mathrm{ml} / \mathrm{rat}$ & $49.46 \pm 4.07$ & $97.95 \pm 0.9$ \\
Diphenoxylate & $5 \mathrm{mg} / \mathrm{kg}$ & $8.37 \pm 0.66^{* * *}$ & $15.92 \pm 0.7 I^{* * *}$ \\
Arque-Ajeeb & $0.07 \mathrm{ml} / \mathrm{kg}$ & $23.42 \pm 1.81^{* *}$ & $33.67 \pm 1.70^{* * *}$ \\
Arque-Ajeeb & $0.14 \mathrm{ml} / \mathrm{kg}$ & $19.99 \pm 0.20^{* * *}$ & $25.79 \pm 0.88^{* * *}$ \\
\hline
\end{tabular}

$* * \mathrm{p}<0.01$ and $* * * \mathrm{P}<0.001$ statistically significant as compared to control value.

Table 2: Effect of $A A$ on serotonin-induced diarrhoea

\begin{tabular}{llllll}
\hline Groups & Doses & \% respondent & $\begin{array}{l}\text { Mean latent period in } \\
\text { hour } \pm \text { S.E.M. }\end{array}$ & $\begin{array}{l}\text { Mean number of stools } \\
\pm \text { S.E.M. }\end{array}$ & Purging indexes \\
\hline Control (saline) & $2 \mathrm{ml} / \mathrm{rat}$ & 100 & $1.33 \pm 0.09$ & $1.00 \pm 00$ & 75.02 \\
Diphenoxylate & $5 \mathrm{mg} / \mathrm{kg}$ & 16.67 & $5.83 \pm 0.15^{* * *}$ & $0.17 \pm 0.15^{* *}$ & $0.48^{* * *}$ \\
Arque-Ajeeb & $0.07 \mathrm{ml} / \mathrm{kg}$ & 33.33 & $5.00 \pm 0.57^{* *}$ & $0.33 \pm 0.19 \mathrm{NS}$ & $2.22^{* * *}$ \\
Arque-Ajeeb & $0.14 \mathrm{ml} / \mathrm{kg}$ & 16.67 & $5.83 \pm 0.15^{* *}$ & $0.17 \pm 0.15^{* *}$ & $0.48^{* * *}$ \\
\hline
\end{tabular}

$*^{*} \mathrm{p}<0.01$ and $*^{* * *} \mathrm{p}<0.00 \mathrm{I}$ statistically significant as compared to control value and ${ }^{\mathrm{NS}} \mathrm{p}>0.05$ (non-significant).

\section{Statistical analysis}

All the values were expressed as mean \pm S.E.M. Student's ttest was used to analyze significance of the two means. Probability level of less than 5\% was considered as statistically significant.

\section{Results}

\section{Effect of AA on charcoal-induced gut transit changes}

In the animals of standard group the total length traveled by activated charcoal was found to be highly significant ( $\mathrm{p}$ $<0.001$ ) as compared to control value at 15 and $30 \mathrm{~min}$ respectively. But after $15 \mathrm{~min} 0.07 \mathrm{ml} / \mathrm{kg}$ dose of $A A$ was found significant $(\mathrm{p}<0.01)$ and $0.14 \mathrm{ml} / \mathrm{kg}$ dose of $A A$ was also found significant $(\mathrm{p}<0.001)$ as compared to control value. Both doses of $A A(0.07 \mathrm{ml}$ and $0.14 \mathrm{ml} / \mathrm{kg})$ were found significant ( $\mathrm{p}<0.001$ ) after $30 \mathrm{~min}$ as compared to control value. The results of study are shown in Table 1.

\section{Effect of $A A$ on serotonin-induced diarrhoea}

The study shows that standard and $A A$ markedly reduces the number of respondents from $100 \%$ to $16.67 \%$, $33.33 \%$ and $16.67 \%$ respectively. The mean latent period of standard was found highly significant $(\mathrm{p}<0.001)$ and both doses of $A A$ viz: $0.07 \mathrm{ml} / \mathrm{kg}(\mathrm{p}<0.01)$ and $0.14 \mathrm{ml} /$ $\mathrm{kg}(\mathrm{p}<0.001)$ were also found significant as compared to control value. The mean numbers of stools of standard and $0.14 \mathrm{ml} / \mathrm{kg}$ dose of $A A$ were found significant $(\mathrm{p}<$ 0.01 ) but $0.07 \mathrm{ml} / \mathrm{kg}$ dose of $A A$ was found non-significant $(\mathrm{p}>0.05)$. However the standard and $A A$ resulted very low purging indexes $(\mathrm{p}<0.001)$. The results of study are shown in Table 2.

\section{Effect of AA on PGE2-induced small intestine enteropooling}

The fluid volume of the rat intestine was significantly increased by $\mathrm{PGE}_{2}$, when compared with the untreated animals (control), which received only ethanol in normal saline and control vehicle $(\mathrm{p}<0.001)$. Both doses of $A A$ $(0.07 \mathrm{ml}$ and $0.14 \mathrm{ml} / \mathrm{kg})$ significantly inhibited $\mathrm{PGE}_{2^{-}}$ induced small intestine enteropooling when compared with the $\mathrm{PGE}_{2}$ treated group ( $\left.\mathrm{p}<0.001\right)$. The results of study are shown in Table 3.

\section{Discussion}

The gastrointestinal tract is innervated by both the parasympathetic and sympathetic fibers of the autonomic nervous system. The peristaltic movement of gastrointestinal tract is myogenic in character and is mainly initiated by the local reflexes and can occur without neural connections to the brain or the spinal cord [10]. The extrinsic nerves to the intestine appear to have only a minor role in modulating the peristaltic activity of the organ [11]. Earlier study shows that activated charcoal avidly absorbs drugs and chemicals on the surface of the charcoal particles thereby preventing absorption [12]. Thus gut transit test with activated charcoal was carried out to find out the effect of $A A$ on peristaltic movement. Our study also shows that $A A$ suppressed the propulsion of charcoal meal in a dose dependent manner. 
Table 3: Effect of $A A$ on $P E_{2}$-induced small intestine enteropooling

\begin{tabular}{lll}
\hline Groups & Doses & Volume of intestinal fluid in ml (Mean \pm S.E.M.) \\
\hline Control (ethanol in saline) & $1 \mathrm{ml} / \mathrm{rat}$ & $0.76 \pm 0.15$ \\
PGE $_{2}$ & $100 \mu \mathrm{kg}$ & $3.15 \pm 0.15^{* * *}$ \\
Arque-Ajeeb & $0.07 \mathrm{ml} / \mathrm{kg}$ & $1.93 \pm 0.18^{* * *}$ \\
Arque-Ajeeb & $0.14 \mathrm{ml} / \mathrm{kg}$ & $1.18 \pm 0.65^{* * *}$
\end{tabular}

*** $\mathrm{p}<0.00$ I statistically significant $\left(\mathrm{PGE}_{2}\right.$ vs. control and $A A$ vs. $\left.\mathrm{PGE}_{2}\right)$.

The use of serotonin induced diarrhoea model in our study is also logical because serotonin itself is a diarrheogenic hormone, which causes contraction of intestinal smooth muscle by two mechanisms, a direct action on smooth muscle and a neurally mediated action. In specific portion of the intestine (i.e. duodenum), the direct action predominates [13], whereas in others (i.e. ileum), the indirect neural effect appears to predominate [14]. In the present study $A A$ inhibited serotonin-induced diarrhoea in a dose dependent manner resulting in very low purging indexes.

In vitro, $\mathrm{PGE}_{2}$ added to the serosal side of small intestine of animals inhibits sodium and chloride absorption from mucosal surface [15]. It causes stimulation of motility and conversion of small intestinal mucosa from absorption to secretion of water and electrolytes. $\mathrm{PGE}_{2}$ also inhibit the absorption of glucose, a major stimulus to intestinal absorption of water and electrolytes [16]. In the present study $A A$ inhibited $P E_{2}$-induced small intestine contents in a dose dependent manner.

Diphenoxylate, which was used as a standard drug to compare the antidiarrhoeal effects of $A A$, seems to exert stronger effects with similar action. Although further investigations are necessary to elucidate the mechanisms by which $A A$ suppressed the charcoal-induced gut transit, serotonin-induced diarrhoea and $\mathrm{PGE}_{2}$-induced small intestine enteropooling. These properties may explain the rational for the extensive and effective use of the $A A$ as an antidiarrhoeal agent in Unani medicine.

\section{Conclusion}

The results of this investigation reveal that the $A A$ contains pharmacologically active substance (s) with antidiarrhoeal properties. Thus we presume that $A A$ can be developed for the treatment of diarrhoea. But to reach any conclusive decision additional models of diarrhoea and more detailed phytochemical studies are necessary to identify the active principle and exact mechanism of action.

\section{Competing interests}

None declared.

\section{Authors' contributions}

MAK - Participated in sequence alignment and experimental work.

NAK - Supervised the design and coordination of the study.

IAQ - Supervised the design, sequence alignment and coordination of the study.

GA - Supervised the design, sequence alignment and coordination of the study.

SZ - Participated in statistical analysis and the drafting of manuscript.

\section{Acknowledgments}

The authors are thankful to the authority of the institution for providing all kind of help needed.

\section{References}

I. Fauci AS, Bravnwold E, Isselpacher K, Wilson JD, Martin JB, Kasper DL, Hauser SL, Longo DL: Harrison's Principles of Internal Medicine. Volume I. New York, McGraw Hill Company; 1998:236-242.

2. Park K: Park's Textbook of Preventive and Social Medicine. Jabalpur, India, M/S Banarsidas Bharat Publishers; 2000:172-175.

3. Khan A: Bayaz-e-Ajmal. Delhi, India, Aijaz Publishing House; 1995:231.

4. Gilani Gl: Makhzanul Murakkabat Wa Mouallim-e-Dawa Sazi. Delhi, India, Kutub Khana Anjuman Taraqqi Urdu; 1938:250.

5. Qarshi MH: Tibbi Pharmacopia. Volume I. Lahore, Pakistan, Kareemi Press; 1985:330.

6. Anonymous: National Formulary of Unani Medicine. New Delhi, India, Ministry of Health and Family Welfare 1993, I:3 I8.

7. Khan AG: Maseehul Mulk Ke Murakkabat. Haryana, India, Urdu Dawakhana | 985, II: 196.

8. Jabbar S, Khan MTH, Choudhuri MSK, Gafur MA, Ahmad K: Effect of Semicarpus anacardium Linn. on acute experimental diarrhoea. Ham Med 1999, XLII:48-53.

9. Biswas S, Murugesan T, Sinha S, Maiti K, Gayen, Pal M, Saha BP: Antidiarrhoeal activity of Strychnos potatorum seeds extract in rats. Fitoterapia 2002, 73:43-47.

10. Shahriar M, Bhuiya MS, Khan MTH, Gafur MA, Choudhri MSK: Pharmacological study of Symplocos racemosa Roxb. Ham Med 2000, XLIII:8-I8.

II. Pierce NF, Carpenter CCJ, Elliot HI, Greenough WB: Effects of prostaglandins, theophylline and cholera exotoxin upon 
transmucosal water and electrolyte movement in canine jejunum. Gastroenterol 1971, 60:22-32.

12. Levy G: Gastrointestinal clearance of drugs with activated charcoal. New Eng J Med 1982, 307:676-678.

13. Drakontides $A B$, Gershon MD: 5-hydroxytryptamine receptors in the mouse duodenum. $\mathrm{Br} J$ Pharmacol Chemother 1968, 33:480-492.

14. Day M, Vane JR: An analysis of the direct and indirect actions of drugs on the isolated guinea-pig ileum. $\mathrm{Br} J$ Pharmacol Chemother 1963, 20:150-170.

15. Declusin R, Wall M, Whalen G: Effect of prostaglandin $E_{2}\left(P_{G} E_{2}\right)$ on sodium and chloride transport in rat jejunum. Clin Res 1974, 22:635A.

16. Jaffe BM: Prostaglandins and serotonin: Nonpeptide diarrheogenic hormones. World J Surg 1979, 3:565-578.

\section{Pre-publication history}

The pre-publication history for this paper can be accessed here:

http://www.biomedcentral.com/1472-6882/4/8/prepub

Publish with Bio Med Central and every scientist can read your work free of charge

"BioMed Central will be the most significant development for disseminating the results of biomedical research in our lifetime. "

Sir Paul Nurse, Cancer Research UK

Your research papers will be:

- available free of charge to the entire biomedical community

- peer reviewed and published immediately upon acceptance

- cited in PubMed and archived on PubMed Central

- yours - you keep the copyright

Submit your manuscript here:

http://www.biomedcentral.com/info/publishing_adv.asp 